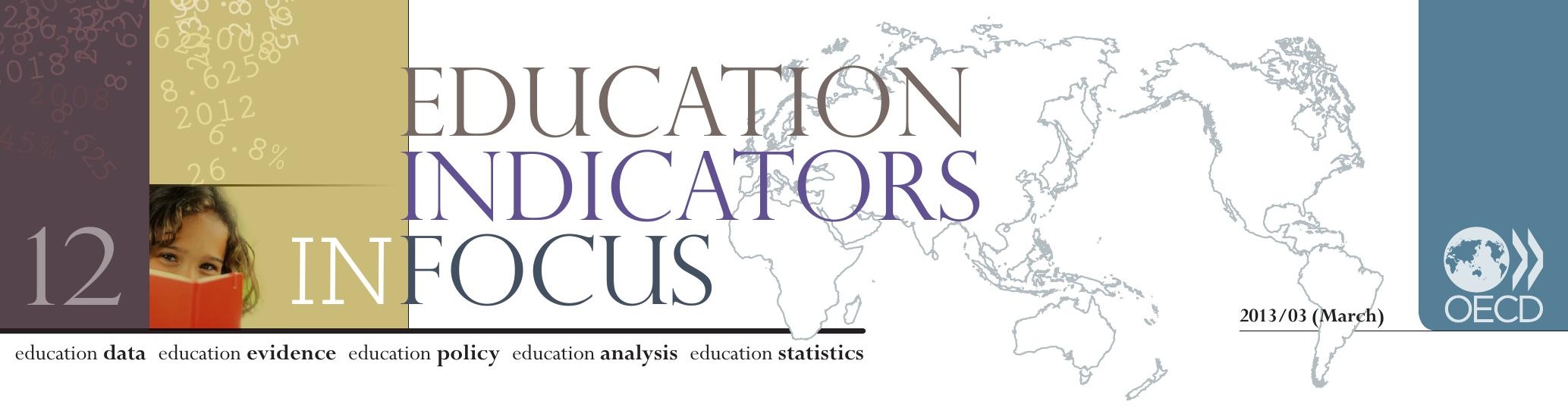

\title{
Which factors determine the level of expenditure on teaching staff?
}

- The higher the level of education, the higher the salary cost of teachers per student. In Belgium (Flemish Community), France and Spain, the difference in the annual salary cost between the primary and upper secondary levels of education exceeds USD 1800 in 2010.

- Between $\mathbf{2 0 0 0}$ and 2010, the salary cost of teachers per student increased in nearly all countries at the primary and lower secondary levels of education and, on average, by one-third and one-quarter respectively.

- Changes over time in the level of salary cost of teachers are mainly driven by teachers' salaries; class size is the second main driver.

- Similar levels of expenditure among countries can mask a variety of contrasting policy choices.

The relationship between the resources devoted to education and the outcomes achieved by students has been a significant area of focus among OECD governments.

On the one hand, governments seek to provide more and better education for their populations. On the other hand, given the increasing pressure on public budgets, the efficient use of public funding to achieve the desired outcomes is a priority.

The salary cost of teachers is the main source of expenditure on education in all OECD countries. It is the result of the mathematical combination of four factors: teachers' salaries, class size, the number of teaching hours in front of a classroom for a teacher and the number of hours of instruction received by pupils (see Box B7.1 in OECD, 2012).

Consequently, a given level of expenditure on teaching staff may result from different combinations of these four factors. Similarly, a reform (or a structural change) to one of these factors (all of the other factors remaining the same) has a direct impact on the level of expenditure: i) increasing teachers' salaries leads to an increase of the public budget; ii) decreasing class size implies a need for additional teachers, thus increasing the public budget; iii) increasing the number of hours of instruction received by pupils or decreasing the number of teachers' teaching hours results in a need for additional teachers, thus increasing the public budget.

The higher the level of education, the higher the salary cost of teachers per student, but there are great disparities between OECD countries.

Spending on education exhibits a common pattern across OECD countries: it rises sharply with the level of education. On average between OECD countries with available data, the salary cost of teachers in 2010 was USD 2307 per primary student, USD 2856 per lower secondary student and USD 3301 per upper secondary student (see chart on page 2). There is a difference of less than USD 50 in Chile and Hungary between the different levels of education, but the difference is over USD 1800 in Belgium (French Community), France and Portugal, and exceeds USD 2000 in Belgium (Flemish Community). 
Salary cost (in USD) of teachers per student, by level of education (2010)

\begin{tabular}{lllll}
\hline USD \\
12000
\end{tabular}

Countries are ranked in descending order of the salary cost of teachers per student in lower secondary education. Source: OECD, Education at a Glance 2012: OECD Indicators, Indicator B7 (www.oecd.org/edu/eag2012).

This is partly the result of increases in teachers' salaries and in the instruction time of students at higher educational levels (see table below). It is also related to the fact that teaching time generally decreases as the level of education increases (implying that more teachers are necessary to teach a given number of pupils). Increasing class size at higher levels of education tends to decrease the salary cost per student. These differences between countries also result from differences in their levels of wealth.

\section{OECD average for the four factors composing the salary cost of teachers per student, by level of education (2010)}

\begin{tabular}{l|c|c|c} 
& Primary education & Lower secondary education & Upper secondary education \\
\hline Teachers' salaries & USD 38162 & USD 39873 & USD 41 182 \\
\hline $\begin{array}{l}\text { Class size } \\
\begin{array}{l}\text { Number of teaching hours in front } \\
\text { of a classroom for a teacher }\end{array}\end{array}$ & 17 pupils & 18 pupils & 20 pupils \\
$\begin{array}{l}\text { Number of hours of instruction } \\
\text { received by pupils }\end{array}$ & 844 hours & 704 hours & 658 hours \\
\hline
\end{tabular}

\section{Between 2000 and 2010, increases in the salary cost of teachers per student were mainly} influenced by changes in teachers' salaries and class size.

The salary cost of teachers per student at the primary and lower secondary levels increased by one-third and one-quarter, respectively, on average among the countries with available data for both years: from USD 1733 to USD 2307 at the primary level and from USD 2273 to USD 2856 at the lower secondary level. France and Italy are the only countries where the salary cost of teachers per student (slightly) decreased during the same period. In France, this was mainly the result of decreasing salaries, and in Italy of a decreasing number of instruction hours for pupils.

More generally, at both the primary and lower secondary levels of education, the increase was mostly influenced by the changes in teachers' salaries and class size. Between 2000 and 2010, among countries with available data for this period, teachers' salaries (expressed in constant prices) increased on average by $16 \%$ at the primary level and by $14 \%$ at the lower secondary level, whereas class sizes decreased on average by about $14 \%$ at the primary level and by $7 \%$ at the lower secondary level. 
Teachers' salaries increased in real terms in most countries with comparable data for 2000 and 2010, with the largest increases - well over 50\% - seen in the Czech Republic, Estonia and Turkey. On the contrary, in more than three-quarters of the countries, class size tended to decrease in primary education during the same period, most notably in countries that had a relatively large estimated class 50010 size in 2000 (for example, the Czech Republic, Ireland, Japan, Korea and Turkey) (see chart below). In some cases, the significant decreases in class size (leading to an increase in the salary cost of teachers) were not the consequence of a policy decision, but rather the result of demographic changes and declining student numbers.

There was little or no change with respect to the two other factors (instruction time and teaching time) on average during the same period. This can be interpreted as a sign of the potential sensitivity of reforms in these areas. Nevertheless, in a small number of countries, instruction time and/or teaching time did change significantly. At the primary level, teaching time increased most significantly in the Czech Republic, with an increase of 200 hours of teaching time between 2000 and 2010 (teachers' salaries also doubled in the Czech Republic during this time). During this period, instruction time increased the most in Iceland (by nearly 200 hours).

Reforms relating to these four factors have an impact on education expenditure, and may also affect educational outcomes. However, the link between expenditure and outcomes is not straightforward. Over the 2000-09 period, PISA results show that the performance of 15-year-olds did not vary significantly in the majority of countries (see OECD, 2010), even if changes were made to education policy relating to instruction time, teaching time, class size or teacher compensation. Moreover, changes relating to pedagogy may also impact on outcomes without necessarily increasing/ decreasing expenditure.

\section{Change in the salary cost of teachers per student, teachers' salaries and estimated class size in primary and lower secondary education (between 2000 and 2010, in percentage)}

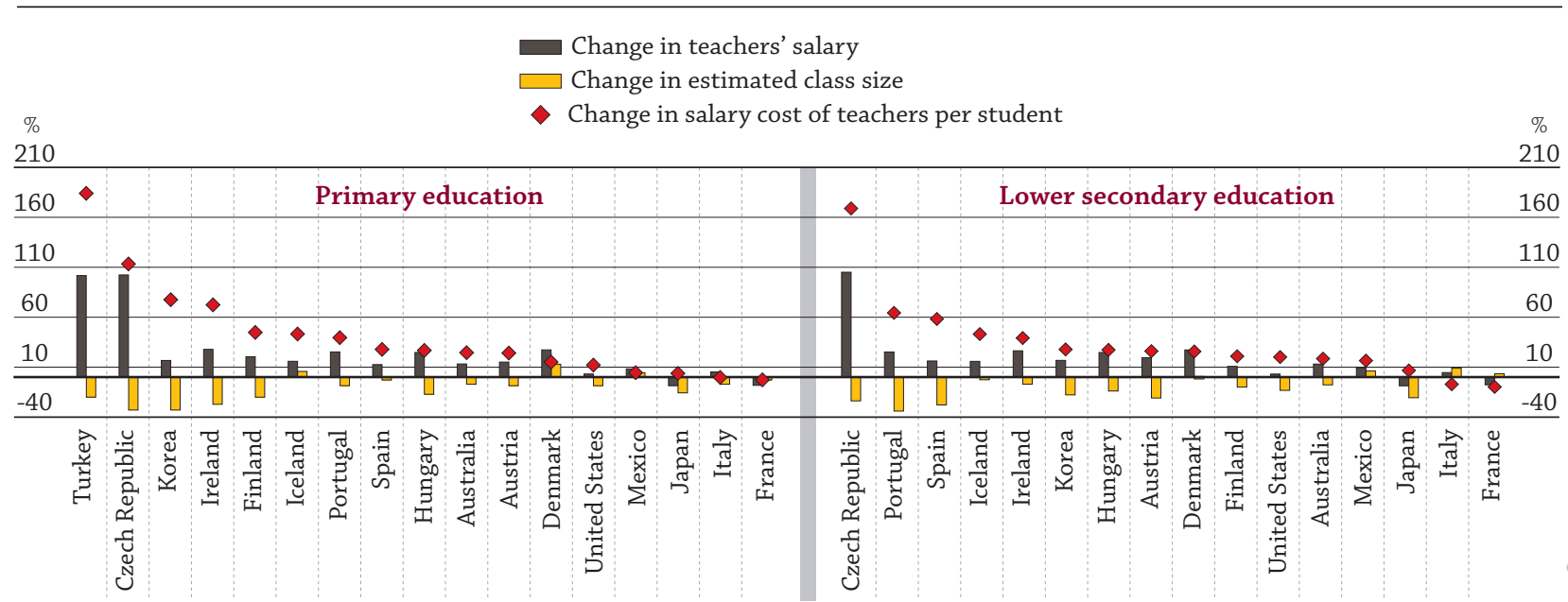

Countries are ranked in descending order of the change in the salary cost of teachers per student between 2000 and 2010. Source: OECD, Education at a Glance 2012: OECD Indicators, Indicator B7 (www.oecd.org/edu/eag2012).

Similar levels of expenditure among countries can mask a variety of contrasting policy choices.

Higher levels of expenditure on education cannot automatically be equated with better performance by education systems, as can be seen when comparing the average performance of 15-year-olds on the PISA 2009 reading literacy scale with the cumulative spending per student between the ages of 6 and 15 in 2009.

This is not surprising, as countries spending similar amounts on education do not necessarily have similar education policies and practices. For example, at the upper secondary level of education, Germany and Spain have similar levels of salary costs of teachers per student (at, respectively, USD 5052 and USD 5 100), both higher than the OECD average. 


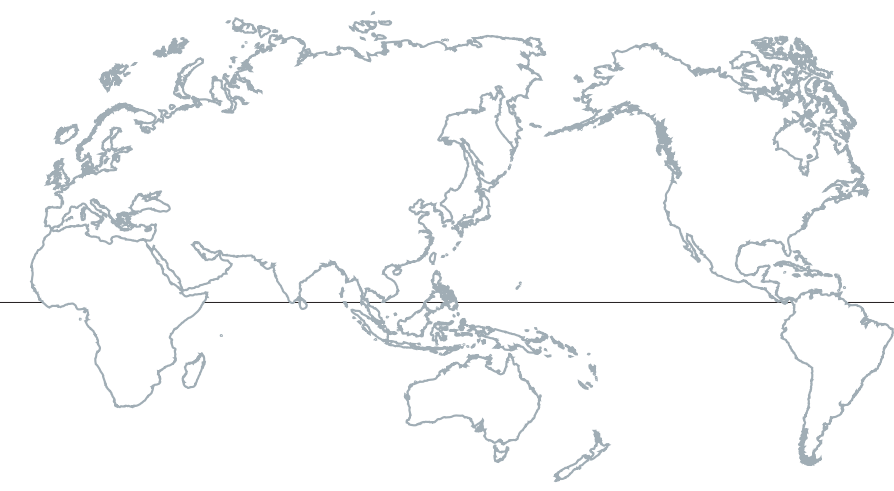

This mainly results from teachers' salaries that are significantly higher than average salaries in Germany, whereas in Spain, it results from the combination of below-average estimated class size, above-average instruction time and above-average salaries of teachers.

Contribution (in USD) of various factors to salary cost of teachers per student, at the upper secondary level of education (2010)

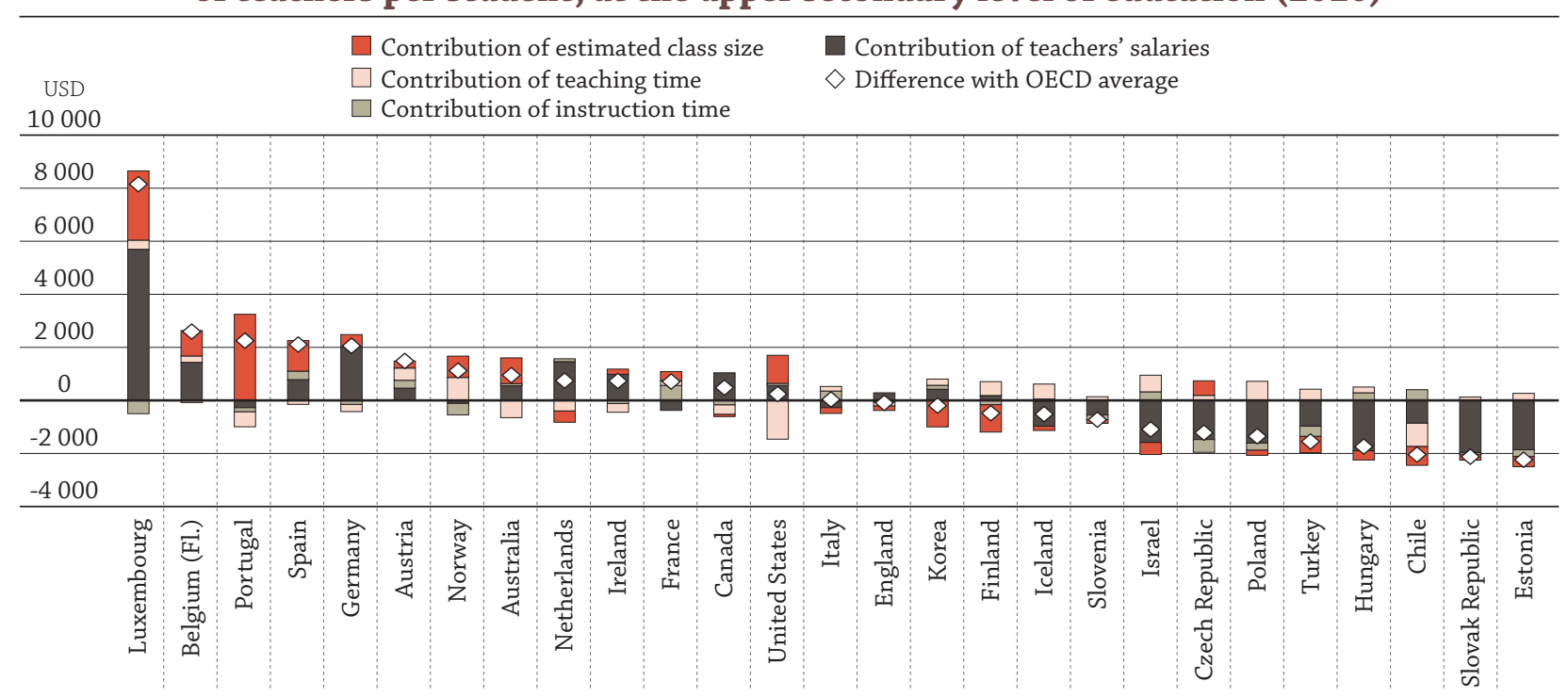

Countries are ranked in descending order of the difference between the salary cost of teacher per student and the OECD average. Source: OECD, Education at a Glance 2012: OECD Indicators, Indicator B7 (www.oecd.org/edu/eag2012).

Alongside such contrasts, there are also striking similarities in countries' policy choices, even if these similarities can result in different levels of salary cost of teachers per student. For example, in Australia, New Zealand, the United Kingdom and the United States, the salary cost of teachers per student at the upper secondary level is the result of balancing two opposing effects: above-average teaching time acts to reduce the salary cost of teachers per student relative to the OECD average, and relatively small class size increases the salary cost of teachers per student relative to the OECD average. However, the salary cost of teachers per student resulting from this combination is above the OECD average in Australia and the United Kingdom, but below the OECD average in New Zealand and the United States, where teaching time and class size are closer to the OECD averages than in the first two countries.

The bottom line In nearly all countries, the salary cost of primary and lower secondary teachers significantly increased between 2000 and 2010. This increase was mainly driven by rising teachers' salaries and decreasing class size. Better paid teachers and smaller classes have exerted an upward pressure on educational spending. PISA data for the same period show that these policies have not yet resulted in significant improvements in learning outcomes for the majority of countries.

\begin{tabular}{l|l}
$\begin{array}{l}\text { Visit: } \\
\text { www.oecd.org/edu/ } \\
\text { eag2012 }\end{array}$ & $\begin{array}{l}\text { See: } \\
\text { OECD (2012), Education at a Glance 2012: }\end{array}$ \\
& $\frac{\text { OECD Indicators, OECD Publishing. }}{\text { OECD (2010), PISA 2009 Results: Learning Trends: }}$ \\
& $\frac{\text { Changes in Student Performance Since 2000 }}{\text { (Volume V), PISA, OECD Publishing. }}$
\end{tabular}

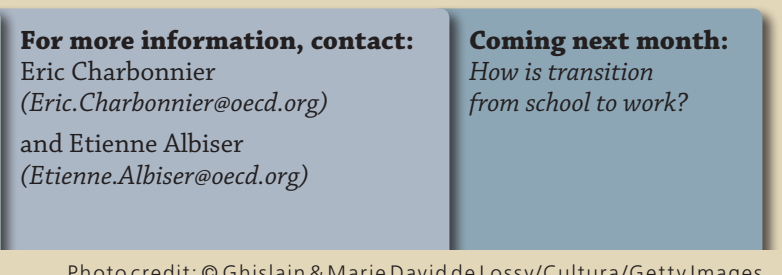

Photo credit: $\odot$ Ghislain \& Marie David de Lossy/Cultura/Getty Images 